The Bangladesh Veterinarian (2013) 30(2) : 62 - 69

\title{
Prevalence of surgical diseases of cattle in stall-fed and free- range cattle in Bangladesh
}

\author{
NU Sarker, MM Rahman*, MS Rana, MT Islam and UK Rima ${ }^{1}$ \\ Department of Surgery and Obstetrics, Faculty of Veterinary Science, Bangladesh \\ Agricultural University, Mymensingh-2202, Bangladesh
}

\begin{abstract}
The prevalence of surgical diseases of 2081 cattle was studied from different free-ranging (Bathan) and stall-feeding systems. The overall prevalence of surgical disease of cattle was higher (53.2\%) in Bathan than in the stall-feeding (37.5\%) system. In Bathan, the most prevalent surgical diseases were myiasis $(13.4 \%)$ followed by navel ill $(12.5 \%)$, trauma $(10.8 \%)$, claw diseases $(7.6 \%)$, arthritis $(6.1 \%)$, horn diseases $(3.4 \%)$ and teat obstruction $(2.6 \%)$. In stall-feeding system, the highest prevalence (10.6\%) was claw diseases and navel ill (6.6\%). Navel ill, hernia, arthritis, horn diseases, urolithiasis and tail gangrene were more prevalent in male; and claw diseases, trauma, myiasis, upward patellar fixation and dislocation of hip joint were more prevalent in female cattle. Most diseases were more prevalent in summer but claw diseases, urolithiasis and teat crack were more prevalent in winter. Clean environment is needed to reduce the prevalence of such problems. (Bangl. vet. 2013. Vol. 30, No. 2, 62 - 69)
\end{abstract}

\section{Introduction}

Cattle are the indispensable part of the livestock sub-sector in Bangladesh. The magnitude of contribution of the livestock sector to the GDP is $2.6 \%$ in Bangladesh (Anon, 2010). However, surgical disorders are the major causes of fatality in animals. The commonest surgical anomalies are umbilical hernia, atresia ani, navel ill, gangrenous mastitis, teat obstruction, teat crack, and lameness (Hossain et al., 1986; Samad, 1998). Failure of surgical intervention provides no alternative except culling (Berge and Westhues, 1986). However, there is no data on the prevalence of surgical diseases in cattle of Milk-Vita area of Pabna-Sirajginj districts in Bangladesh. A comprehensive survey is necessary to establish baseline information for future strategy.

\section{Materials and Methods}

\section{Survey population}

This study was conducted in Milk-Vita area of Pabna-Sirajgonj districts. The data were collected randomly from 1033 cattle in free-ranging (Bathans) and 1048 in stallfeeding systems of different villages of five Upazilas (Sub-district).

\footnotetext{
1Department of Medicine, Surgery and Obstetrics, Faculty of Veterinary \& Animal Sciences, Hajee Mohammad Danesh Science and Technology University, Dinajpur, Bangladesh

*Corresponding author:- E-mail: miznih@gmail.com
} 
Survey

History of the problems was taken from the owner and animal attendant (Moshal) about the surgical diseases of the animals. Some of the affected cattle were clinically examined.

Sex was considered as one of the variables for analyzing the data. On the basis of climatic conditions, the prevalence of surgical diseases in summer, rainy and winter seasons was done.

\section{Statistical analysis}

The prevalence of surgical diseases in each area was calculated. The prevalence of surgical diseases in Bathans and stall-feeding systems, in male and female, and in different seasons was compared.

\section{Results and Discussion}

The prevalence (\%) of various surgical diseases of cattle in Bathans is presented in Table 1. The highest prevalence was myiasis (13.4\%) followed by navel ill (12.5\%), trauma $(10.8 \%)$ and claw diseases $(7.6 \%)$. The prevalence of myiasis was highest in Bathan and fourth highest rate was in stall-feeding system. This result is similar to the report (9.5\%) of Rahman et al. (1972). Myiasis is more prevalent in female and in summer season (Spradbery et al., 1992).

The prevalence of surgical diseases of stall-fed cattle in five Upazila is presented in Table 2. The highest prevalence of surgical diseases were claw diseases $(10.6 \%)$ followed by navel ill (6.6\%), trauma (4.3\%) and myiasis (3.6\%). Artesia ani was almost absent $(0.3 \%)$. It may be due to recessive gene acquired through the practice of artificial insemination between local and high yielding animal (Singh et al., 1989; Hossain, 2011).

In stall-feeding system the most prevalent surgical disease was claw diseases (10.6\%), which was the fourth most common (7.6\%) in Bathans (Fig. 1). It may be due to concrete floor of the animal shed and feeding of more concentrates, lack of exercise and little or no green grass/roughage. The prevalence of claw disease was higher in winter $(60.4 \%)$ than summer $(18.9 \%)$. White hooves are more susceptible to lameness than black hooves, and black hooves are more common in Jerseys (Chesterton et al., 1989; Tranter and Morris, 1991). The occurrence of claw diseases was $8 \%$ in Mymensingh district (Das, 2004) and 11.5\% in North Bengal of Bangladesh (Uddin et al., 1997). The prevalence of claw disease was higher in female $(73.9 \%)$ than male $(26.1 \%)$. The incidence of foot diseases in female is $92.4 \%$ has been reported (Gogoi et al., 1981). 
Table 1. Prevalence of surgical diseases of cattle in different Bathans of PabnaSirajgonj districts

\begin{tabular}{l|c|c|c|c|c|c}
\hline \multicolumn{1}{c}{ Name of diseases } & $\begin{array}{c}\text { Harni } \\
\mathrm{n}=355 \\
(\%)\end{array}$ & $\begin{array}{c}\text { Moddo Kawak } \\
\mathrm{n}=364 \\
(\%)\end{array}$ & $\begin{array}{c}\text { Itakhola } \\
\mathrm{n}=17 \\
(\%)\end{array}$ & $\begin{array}{c}\text { Jamadar } \\
\text { (South) } \\
\mathrm{n}=81(\%)\end{array}$ & $\begin{array}{c}\text { Jamadar } \\
(\text { North) } \\
\mathrm{n}=58(\%)\end{array}$ & $\begin{array}{c}\text { Total } \\
\mathrm{n}=1033 \\
(\%)\end{array}$ \\
\hline Hernia & 1.7 & 3.3 & 3.4 & 2.5 & 1.7 & 2.6 \\
Upward patellar fixation & 0.3 & 0.8 & 1.1 & 1.2 & 0.0 & 0.7 \\
Dermoid cyst & 1.7 & 2.8 & 4.0 & 1.2 & 3.5 & 2.5 \\
Navel ill & 7.9 & 11.0 & 20.0 & 17.3 & 20.7 & 12.5 \\
Gangrenous mastitis & 0.0 & 0.6 & 1.1 & 1.2 & 0.0 & 0.5 \\
Teat obstruction & 2.5 & 1.4 & 1.7 & 7.4 & 6.9 & 2.6 \\
Teat crack & 2.0 & 5.5 & 6.9 & 5.0 & 5.2 & 4.5 \\
Horn diseases & 5.6 & 1.9 & 2.9 & 3.7 & 0.0 & 3.4 \\
Dislocation of hip joint & 1.7 & 1.4 & 2.9 & 0.0 & 1.7 & 1.7 \\
Claw diseases & 9.0 & 6.3 & 5.7 & 6.2 & 13.8 & 7.6 \\
Fracture & 0.9 & 0.8 & 0.0 & 1.2 & 0.0 & 0.7 \\
Myiasis & 8.7 & 14.3 & 21.7 & 9.9 & 15.5 & 13.4 \\
Urolithiasis & 0.0 & 0.3 & 0.6 & 0.0 & 0.0 & 0.2 \\
Arthritis & 2.8 & 6.9 & 8.6 & 11.1 & 7.0 & 6.1 \\
Traumatic wound & 10.1 & 11.0 & 12.6 & 9.9 & 8.6 & 10.8 \\
\hline
\end{tabular}

$\mathrm{n}=$ number of study population

Table 2. Prevalence of surgical diseases of stall-fed cattle in five Upazila of PabnaSirajgonj districts

\begin{tabular}{l|c|c|c|c|c|c}
\hline \multicolumn{1}{c|}{ Name of diseases } & $\begin{array}{c}\text { Santhia } \\
\mathrm{n}=215 \\
(\%)\end{array}$ & $\begin{array}{c}\text { Bera } \\
\mathrm{n}=222 \\
(\%)\end{array}$ & $\begin{array}{c}\text { Shahjadpur } \\
\mathrm{n}=218 \\
(\%)\end{array}$ & $\begin{array}{c}\text { Faridpur } \\
\mathrm{n}=205 \\
(\%)\end{array}$ & $\begin{array}{c}\text { Bhangura } \\
\mathrm{n}=188 \\
(\%)\end{array}$ & $\begin{array}{c}\text { Total } \\
\mathrm{n}=1048 \\
(\%)\end{array}$ \\
\hline Hernia & 3.7 & 2.7 & 3.2 & 2.4 & 1.6 & 2.8 \\
Atresia ani & 0.5 & 0.5 & 0.5 & 0.0 & 0.0 & 0.3 \\
Upward patellar fixation & 1.4 & 1.4 & 1.8 & 2.4 & 1.6 & 1.7 \\
Dermoid cyst & 2.3 & 1.8 & 2.8 & 2.0 & 1.6 & 2.1 \\
Navel ill & 7.9 & 5.0 & 7.3 & 5.4 & 7.4 & 6.6 \\
Urolithiasis & 0.9 & 0.9 & 0.9 & 0.5 & 0.5 & 0.8 \\
Dislocation of hip joint & 0.5 & 0.5 & 0.0 & 0.5 & 0.0 & 0.3 \\
Horn diseases & 3.7 & 2.7 & 3.2 & 2.0 & 1.6 & 2.7 \\
Claw diseases & 9.8 & 10.4 & 13.3 & 10.2 & 9.0 & 10.6 \\
Fracture & 0.5 & 0.5 & 0.0 & 0.0 & 0.0 & 0.2 \\
Myiasis & 4.7 & 3.6 & 3.7 & 3.4 & 2.7 & 3.6 \\
Humpsore & 0.5 & 0.0 & 0.5 & 0.5 & 0.0 & 0.3 \\
Arthritis & 3.3 & 1.8 & 3.2 & 4.9 & 4.8 & 3.5 \\
Tail gangrene & 0.5 & 0.5 & 0.0 & 0.0 & 0.5 & 0.3 \\
Trauma & 6.1 & 5.4 & 3.7 & 3.4 & 2.7 & 4.3 \\
Gangrenous mastitis & 0.5 & 0.5 & 0.0 & 0.0 & 0.5 & 0.3 \\
Teat obstruction & 2.3 & 2.7 & 3.2 & 3.9 & 3.2 & 3.1 \\
Teat crack & 1.4 & 1.4 & 1.4 & 1.5 & 1.1 & 1.3 \\
\hline
\end{tabular}

$\mathrm{n}=$ number of study population 


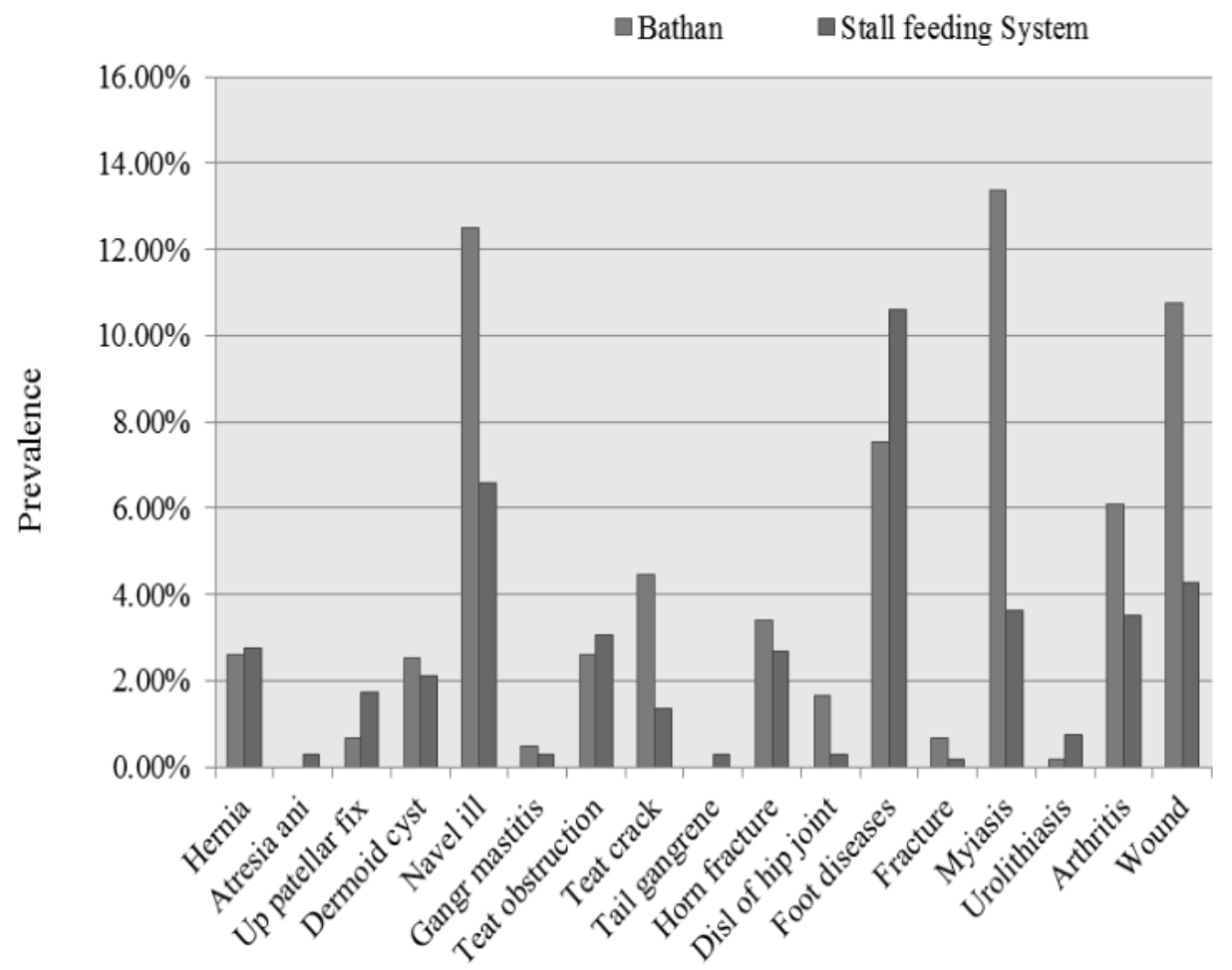

Fig. 1. Comparison of prevalence of common surgical diseases of cattle between Bathan and stall-feeding system

The prevalence of upward patellar fixation was more in stall feeding system $(1.7 \%)$ than Bathan $(0.7 \%)$. But Das (1986) reported the occurrence of upward patellar fixation was 1.2\% in Bangladesh. Incidence of upward fixation of patella was higher $(48 \%)$ in winter (Tyagi et al., 1972; Sharma et al., 1984), but in the present study the prevalence was highest in summer $(50 \%)$. Pregnant female cattle are most often affected with upward patellar fixation (Hanson and Peyton, 1987).

The prevalence of horn diseases was 3.4\% in Bathan and 2.7\% in stall feeding systems, comparable with Das (1986) who reported $3.6 \%$, but lower than the $8.2 \%$ reported by Hossain et al. (1986). Free ranging zebu type animals' fight, may cause higher prevalence of horn disease.

The prevalence of hernia is higher $(2.8 \%)$ in stall feeding system than Bathan (2.6\%). Occurrence of umbilical hernia in Bangladesh was reported by Hossain et al. (1986) and Das (1986) at $0.8 \%$ and $0.9 \%$, respectively. Improvement of cattle depends on crossing local breeds with high-yielding breeds. This may cause inherited surgical diseases in this area (Rahman et al., 2001). Umbilical hernia predominantly found in the summer and declines in the winter (Brem et al., 1985; Rahman et al., 2001; Samad et al., 2002; Islam, 2005). It may be due to more calves are born in summer than the winter season in Bangladesh. 
Table 3. Effects of sex on surgical diseases of stall-fed cattle

\begin{tabular}{l|c|c|c|c}
\hline \multirow{2}{*}{ Name of diseases } & \multicolumn{2}{c|}{ Male $(\mathrm{n}=292)$} & \multicolumn{2}{c}{ Female $(\mathrm{n}=756)$} \\
\cline { 2 - 5 } & Number & Prevalence $(\%)$ & Number & Prevalence (\%) \\
\hline Hernia & 18 & 6.2 & 11 & 1.5 \\
Atresia ani & 2 & 0.7 & 1 & 0.1 \\
Upward patellar fixation & 3 & 1.0 & 15 & 2.0 \\
Dermoid cyst & 14 & 4.79 & 8 & 1.1 \\
Navel ill & 44 & 15.1 & 25 & 3.3 \\
Urolithiasis & 8 & 2.7 & 0 & 0.0 \\
Dislocation of hip joint & 0 & 0.0 & 3 & 0.4 \\
Horn diseases & 16 & 5.5 & 12 & 1.6 \\
Claw diseases & 29 & 9.9 & 82 & 10.9 \\
Fracture & 0 & 0.0 & 2 & 0.3 \\
Myiasis & 8 & 2.7 & 30 & 4.0 \\
Humpsore & 3 & 1.0 & 0 & 0.0 \\
Arthritis & 23 & 7.9 & 14 & 1.9 \\
Tail gangrene & 3 & 1.0 & 0 & 0.0 \\
Traumatic wound & 11 & 3.8 & 34 & 4.5 \\
Gangrenous mastitis & 0 & 0.0 & 3 & 0.4 \\
Teat obstruction & 0 & 0.0 & 32 & 4.2 \\
Teat crack & 0 & 0.0 & 14 & 1.9 \\
Total diseases & 182 & & 286 & \\
Total affected cattle & 149 & & 244 & \\
Overall prevalence & & 51.0 & & 32.3 \\
\hline
\end{tabular}

The prevalence of navel ill was higher $(12.5 \%)$ in Bathan than in stall feeding system $(6.6 \%)$. It is due to unhygienic condition of the Bathan and lack of health care of newborns in the crowded population. Similar reports have been documented earlier, $6.6 \%$ prevalence in Pabna district of Bangladesh (Kibria et al., 2010). The prevalence of navel ill is more in male $(63.8 \%)$ than female $(36.2 \%)$. It may be due to the presence of prepuce that favours the entrance of bacteria to the umbilical cord (Rings, 1995; Ganga et al., 2011).

The prevalence of teat obstruction was $3.1 \%$ in stall feeding system and $2.6 \%$ in Bathan. The difference may be due to chronic mastitis, unhygienic milking and poor care of udder health (Gonzalez et al., 1990). Teat crack was more prevalent in winter $(57.1 \%)$. Decreased humidity in winter leads the skin of udder to crack (Radostits et al, 2000; Berry and Hillerton, 2002). 
Table 4. Effects of season on surgical diseases of stall-fed cattle

\begin{tabular}{|c|c|c|c|c|c|c|}
\hline \multirow[t]{2}{*}{ Name of diseases } & \multicolumn{2}{|c|}{$\begin{array}{c}\text { Summer } \\
\text { (March-June) }\end{array}$} & \multicolumn{2}{|c|}{$\begin{array}{l}\text { Rainy Season } \\
\text { (July-October) }\end{array}$} & \multicolumn{2}{|c|}{$\begin{array}{c}\text { Winter } \\
\text { (November-February) }\end{array}$} \\
\hline & Number & $\begin{array}{c}\text { Prevalence } \\
(\%)\end{array}$ & Number & $\begin{array}{c}\text { Prevalence } \\
(\%)\end{array}$ & Number & $\begin{array}{c}\text { Prevalence } \\
(\%)\end{array}$ \\
\hline Hernia & 18 & 62.1 & 4 & 13.8 & 7 & 24.1 \\
\hline Atresia ani & 1 & 33.3 & 0 & 0.0 & 2 & 66.7 \\
\hline $\begin{array}{l}\text { Upward patellar } \\
\text { fixation }\end{array}$ & 9 & 50.0 & 4 & 22.2 & 5 & 27.8 \\
\hline Dermoid cyst & 10 & 45.5 & 5 & 22.7 & 7 & 31.8 \\
\hline Navel ill & 32 & 46.4 & 15 & 21.7 & 22 & 31.9 \\
\hline Urolithiasis & 1 & 12.5 & 1 & 12.5 & 6 & 75.0 \\
\hline $\begin{array}{l}\text { Dislocation of hip } \\
\text { joint }\end{array}$ & 2 & 66.7 & 1 & 33.3 & 0 & 0.0 \\
\hline Horn diseases & 18 & 64.3 & 7 & 25.0 & 3 & 10.7 \\
\hline Foot diseases & 21 & 18.9 & 23 & 20.7 & 67 & 60.4 \\
\hline Fracture & 1 & 50.0 & 1 & 50.0 & 0 & 0.0 \\
\hline Myiasis & 19 & 50.0 & 12 & 31.6 & 7 & 18.4 \\
\hline Humpsore & & 33.3 & 2 & 66.7 & 0 & 0.0 \\
\hline Arthritis & 17 & 46.0 & 11 & 29.7 & 9 & 24.3 \\
\hline Tail gangrene & 1 & 33.3 & 0 & 0.0 & 2 & 66.7 \\
\hline Traumatic wound & 31 & 68.9 & 9 & 20.0 & 5 & 11.1 \\
\hline $\begin{array}{l}\text { Gangrenous } \\
\text { mastitis }\end{array}$ & 0 & 0.0 & 1 & 33.3 & 2 & 66.7 \\
\hline Teat obstruction & 13 & 40.6 & 4 & 12.5 & 15 & 46.9 \\
\hline Teat crack & 4 & 28.6 & 2 & 14.3 & 8 & 57.1 \\
\hline Total & 199 & 42.5 & 102 & 21.8 & 167 & 35.7 \\
\hline
\end{tabular}

The prevalence of urolithiasis was higher in Bathan than stall-fed cattle. Insufficient green grass with too much concentrate is provided in stall feeding system. Vitamin A deficiency and concentrate diet predispose to urolithiasis (Singh et al., 1980; Ahmed et al., 1990).

\section{Conclusions}

Surgical diseases were more prevalent in Bathans than in stall-feeding system. A cleaner environment should help to maintain cattle health. 


\section{References}

Ahmed AS, Amer HA, Ibrahim IM 1990: Influence of dietary mineral imbalance on the incidence of urolithiasis in Egyptian calves. Journal of Veterinary Medicine 60609.

Anon 2010: Economic review. Livestock subsector, Department of Livestock Service (DLS), Bangladesh.

Berge C, Westhues TS 1986: Veterinary Operative Surgery, Denmark, Medical Book Company, Bonleverd. pp. 148.

Berry E, Hillerton JE 2002: The effect of an intramammary seal on new intramammary infections. Journal of Dairy Science 85 2512-2520.

Brem G, Hondele J, Distl O, Hrausslich H 1985: Investigation of the occurrence and causes of umbilical hernia in German brown calves. Tierarztliche Umschau 40 877-882.

Chesterton RN, Pfeiffer DU, Morris RS, Tanner CM 1989: Environmental and behavioral factors affecting the prevalence of foot lameness in Newzeland dairy herds-case control study. New Zealand Veterinary Journal 39 234-267.

Das BC 1986: Studies on the surgical affections of cattle in Bangladesh. MSc Thesis, Department of Surgery and Obstetrics, Faculty of Veterinary Science, Bangladesh Agricultural University, Mymensingh.

Das BR 2004: Claw affections associated with lameness in cattle. PhD Thesis, Department of Surgery and Obstetrics, Faculty of Veterinary Science, Bangladesh Agricultural University, Mymensingh.

Ganga NS, Ananda KJ, Kavitha RB, Kotresh AM, Shambulingappa BE, Patel SR 2011: Navel ill in new born calves and its successful treatment. Veterinary World 4 326-327.

Gogoi SN, Nigam JM, Singh AP, Chandna IS 1981: Incidence of foot disorders in cattle. Modern Veterinary Practice 62 941-945

Gonzalez RN, Jasper DE, Kronlund NC, Farver TB, Bushnell RB, Ilinger JD 1990: Clinical mastitis in two California dairy herds participating in contagious mastitis control programs. Journal of Dairy Science 73 648-660.

Hanson RR, Peyton LC 1987: Surgical correction of intermittent upward fixation of the patella in a brahman cow. Canadian Veterinary Journal 28 675-677.

Hossain MA, Shahidullah M, Ali MA 1986: Surgical disease and reproductive disorders recorded at the Veterinary Hospital of Bangladesh Agricultural University, Mymensingh, Bangladesh. Bangladesh Veterinary Journal 20 1-5.

Hossain MB 2011: Study on prevalence of atresia ani in calves. MS Thesis, Department of Surgery and Obstetrics, Faculty of Veterinary Science, Bangladesh Agricultural University, Mymensingh.

Islam MS 2005: Studies on umbilical hernia in calves. MS Thesis, Department of Surgery and Obstetrics, Faculty of Veterinary Science, Bangladesh Agricultural University, Mymensingh, Bangladesh. pp 34-38. 
Kibria AS, Khokon MS, Alam MM, Rahman ML, Sarker MS 2010: A comparative study on prevalence of various clinical diseases and disorders of cattle and goat in Pabna district. International Journal of Animal and Fisheries Science 3 257-261.

Radostits OM, Gay CC, Blood DC, Hinchcliff KW 2000: Veterinary Medicine. A Textbook of the Disease of Cattle, Sheep, Pigs, Goats and Horses. 9th edn. Philadelphia, WB Saunders Company. ELBS and Bailliere Tindall, UK pp. 603-687 and 1442-1452.

Rahman MA, Ali KM, Rahman A 1972: Incidence of diseases of cattle in Mymensingh. Bangladesh Veterinary Journal 6 25-30.

Rahman MM, Biwas D, Hossain MA 2001: Occurrence of umbilical hernia and comparative efficacy of different suture materials and technique for its correction in calves. Pakistan Journal of Biological Science 4 1026-1028.

Rings DM 1995: Umbilical hernias, umbilical abscesses and urachal fistulas, surgical consideration. Veterinary Clinics of North America: Food Animal Practice 11 137-148.

Samad MA, Islam MA, Hossain MA 2002: Patterns of occurrence of calf diseases in the district of Mymensingh in Bangladesh. Bangladesh Veterinary Journal 36 01-05.

Samad MA 1998: Veterinary clinician guide. Bangladesh Agricultural University Campus, Mymensingh. Lyric-Epic Prokasoni. pp. 23-45.

Sharma KB, Joshi YG, Tanwar RK 1984: A report on the incidence of upward fixation of patella in bovines of Udaipur area in Rajasthan. Indian Veterinary Journal 61 689-691.

Singh AP, Al Badrany MS, Eshoe SM, Abid TA 1989: Atresia ani and atresia ani et recti in farm animals. Indian Veterinary Journal 5 458-461.

Singh NP, Somvanshi R 1980: Urolithiasis in bovine in Tarai. A pathoanatomical study. Indian Journal of Animal Health 19 19-23.

Spradbery JP, Khanfar KA, Harpham D 1992: Myiasis in the Sultanate of Oman. Veterinary Record 131 76-77.

Tranter WP, Morris RS 1991: A case study of lameness in three dairy herds. New Zealand Veterinary Journal 39 88-96.

Tyagi RP, Krishnamurthy D, Dhablania DC 1972: Upward fixation of patella (stringhalt) in bovines. Indian Veterinary Journal 49934.

Uddin MZ, Hashim MA, Rahman MM 1997: Investigation of lameness in dairy cows in different regions of Bangladesh. Bangladesh Journal of Animal Science 26 83-88. 